\title{
Pastoralist Foodways Recorded in Organic Residues from Pottery Vessels of Modern Communities in Samburu, Kenya
}

\author{
Julie Dunne ${ }^{1}$ (D) Katherine M. Grillo ${ }^{2}$. \\ Emmanuelle Casanova ${ }^{1}$ • Helen L. Whelton ${ }^{1}$. \\ Richard P. Evershed ${ }^{1}$
}

Published online: 15 June 2018

(C) The Author(s) 2018

\begin{abstract}
Organic residue analyses of archaeological ceramics can provide important insights into ancient foodways. To date, however, there has been little critical reflection on how lipid residues might (or might not) reflect dietary practices or subsistence strategies more generally. A combination of ethnoarchaeological research and chemical and isotopic analyses of lipid residues from pottery made and used by modern Samburu pastoralists in northern Kenya was undertaken to supplement the interpretive framework used in archaeological investigations. A total of 63 potsherds were collected from various contexts, including settlement sites and rockshelters, and analysed using gas chromatography (GC), gas chromatography-mass spectrometry (GC-MS) and gas chromatography-combustion-isotope ratio mass spectrometry (GC-C-IRMS). The results showed that the free fatty acids, palmitic $\left(\mathrm{C}_{16: 0}\right)$ and stearic $\left(\mathrm{C}_{18: 0}\right)$, dominated the lipid profiles, with extremely broad ranges of $\delta^{13} \mathrm{C}$ values. The majority of the $\Delta^{13} \mathrm{C}$ values from Samburu pots suggest that vessels were intensively used to process ruminant carcass products, yet the Samburu economy is not, in fact, meat-based at all. Despite an overall reliance on dairy products, milk is rarely processed in ceramic vessels, largely due to cultural prohibitions. Surprisingly, a number of vessels from one site, Naiborkeju Hill, were used to process dairy products. Compound-specific radiocarbon dating of lipids from these sherds suggests that this pottery originated from an earlier period, demonstrating a possible shift in ceramic use by pastoralist communities
\end{abstract}

Julie Dunne and Katherine M. Grillo are joint first authors

Julie Dunne

Julie.Dunne@bristol.ac.uk

1 Organic Geochemistry Unit, School of Chemistry, University of Bristol, Cantock's Close, Bristol BS8 1TS, UK

2 Department of Archaeology and Anthropology, University of Wisconsin - La Crosse, 437G Wimberly Hall, La Crosse, WI 54601, USA 
in this region over time. The overall conclusion is that lipid residues may not necessarily reflect, in a simple way, the day-to-day consumption or the perceived relative importance of different foodstuffs. In the Samburu case, lipid residues reflect the functional and ideological suitability of ceramics for processing only certain types of food (meat/fat/bones), despite an overall reliance on milk. These conclusions are important when considering the origins and development of African pastoralism, for example, as interpreted from the archaeological record.

Keywords Organic residue analysis · Lipids · Pastoralism · Ethnoarchaeology · Foodways $\cdot$ Dairy $\cdot$ Ceramics $\cdot$ East Africa

\section{Introduction}

Analyses of absorbed residues from prehistoric pottery have long been used to answer archaeological questions regarding diet and subsistence practices. A combination of molecular and stable isotopic techniques has, for example, allowed the identification of terrestrial animal fats (ruminant carcass and dairy) as proxies for carcass processing and secondary product exploitation (e.g. Dudd and Evershed 1998; Evershed et al. 2002; Copley et al. 2003; Evershed et al. 2008; Dunne et al. 2012; Debono Spiteri et al. 2016). Likewise, aquatic products (Patrick et al. 1985; Hansel et al. 2004; Craig et al. 2007; Hansel and Evershed 2009; Cramp and Evershed 2014; Cramp et al. 2014; Shoda et al. 2017), plant oils and waxes denoting vegetable and plant oil consumption/ processing (Evershed et al. 1991; Copley et al. 2001a; Copley et al. 2001b; Reber et al. 2004; Copley et al. 2005; Cramp et al. 2011; Dunne et al. 2016) and beeswax (Heron et al. 1994; Charters et al. 1995; Evershed et al. 1997b; Regert et al. 2001; Evershed et al. 2003; Roffet-Salque et al. 2015), resins, tars and bitumen (Beck et al. 1989; Mills and White 1989; Evershed et al. 1997a; van Bergen et al. 1997; Urem-Kotsou et al. 2002; Stern et al. 2003; Buckley et al. 2004; Stern et al. 2008; Connan et al. 2013; Brown et al. 2014: Brettell et al. 2014, 2015) have been identified in connection with a wide range of technological and cultural activities. On a broader scale, lipid residue analyses can provide insight into the domestication of plants and animals, the development of animal husbandry practices and ecological and environmental changes through time (Evershed 2008b; Evershed et al. 2008; Outram et al. 2009; Dunne et al. 2012; Dunne et al. 2016; Roffet-Salque et al. 2017).

A major strength of lipid residue analysis is that it provides direct chemical evidence for commodities processed in ancient vessels and has, on many occasions, been used as a proxy to determine the overall subsistence economies of past communities. Where possible, these data are interpreted in combination with zooarchaeological, archaeobotanical and other archaeological evidence from the relevant site/period. To date, however, there has been little critical reflection on how lipid residues extracted from archaeological ceramics may or may not reflect the potentially complex foodways of ancient peoples more generally. A vital question is whether lipid residues can reflect the relative importance of different foodstuffs in ancient communities, particularly in terms of their daily consumption? Furthermore, can nuances in past people's dietary habits, such as specific practices of cooking or consuming different foods relating to, for example, taboos in food consumption, daily food practices relating to age or 
gendered consumption, or the differential use of vessels due to cultural prohibitions, be determined?

To our knowledge, the only other large-scale lipid analysis previously carried out on an ethnographic assemblage was part of a comprehensive study on pottery function, from the use-alteration perspective, on Kalinga pottery, from the Philippine island of Luzon (Skibo, 1992). However, this study was limited to the extraction of fatty acids and was carried out before the routine use of stable carbon isotope values from fatty acids which permits discrimination between ruminant and non-ruminant adipose and dairy products and aquatic fats and oils. Twenty-five years later, we are now in a position to examine these questions, through a combined molecular and isotopic approach, to pottery made and used in daily life by a contemporary society, Samburu pastoralists in northern Kenya. A sample of sherds were collected from surface contexts at recently occupied open-air settlement and rockshelter sites whilst simultaneously carrying out ethnoarchaeological field research on Samburu pottery and how its production/use/discard relates to subsistence, mobility, and ideology (Grillo 2012, 2014). The potsherds derive from vessels thought to have been used by Samburu over the last 50-100 years. Here, we examine relationships between our ethnographically situated knowledge of Samburu foodways and the chemical analysis of absorbed organic residues in Samburu pots. Critically, we draw new conclusions about the extent to which the multiplicity of daily food-related practices that together constitute a pastoralist way of life are reflected in the lipid residues.

\section{Samburu, Kenya}

Samburu pastoralists live in a semiarid part of north-central Kenya, in an area covering approximately $21,000 \mathrm{~km}^{2}$ in the Rift Valley province (Fig. 1). The topographic and climatic diversity of the Samburu landscape results in a high degree of ecological variability, ranging from the dry scrub desert of the lowlands in the central part of the region to the evergreen forests of the highlands to the west (Shaabani et al. 1992). Cattle are the economic and social centre of Samburu life, and sheep and goats, along with donkeys and camels in drier areas, are also regarded as important livestock. Spencer's classic ethnographies of the Samburu $(1965,1973)$ provided detailed descriptions of settlement patterns and grazing decisions in Samburu; at that time people in many areas were moving their houses every few weeks or months. Residential mobility of this frequency is much less common today, but because patterns of rainfall and the availability of pasture vary both spatially and seasonally, Samburu still move herds of cattle between highlands and lowlands (or further afield) if necessitated by dry seasons or drought. Young unmarried men (lmurran) frequently herd cattle to remote cattle camps, whilst other members of households stay in more permanent homes, particularly in the highlands and on the Lorroki (or Leroghi) Plateau.

The Samburu subsistence system has historically been based on the famous triad of milk, meat and blood common to herding societies living throughout the African continent. Over the last 70 years, however, there has been a distinct shift away from a diet centred predominantly on the products of their herds, towards a diet that includes much greater reliance on foods previously associated primarily with agricultural populations (Grillo 2012, 2014; Holtzman 2007, 2009; Iannotti and Lesorogol 2014a). On some better-watered parts of the Lorroki Plateau to the southwest and in the Mbaringon 


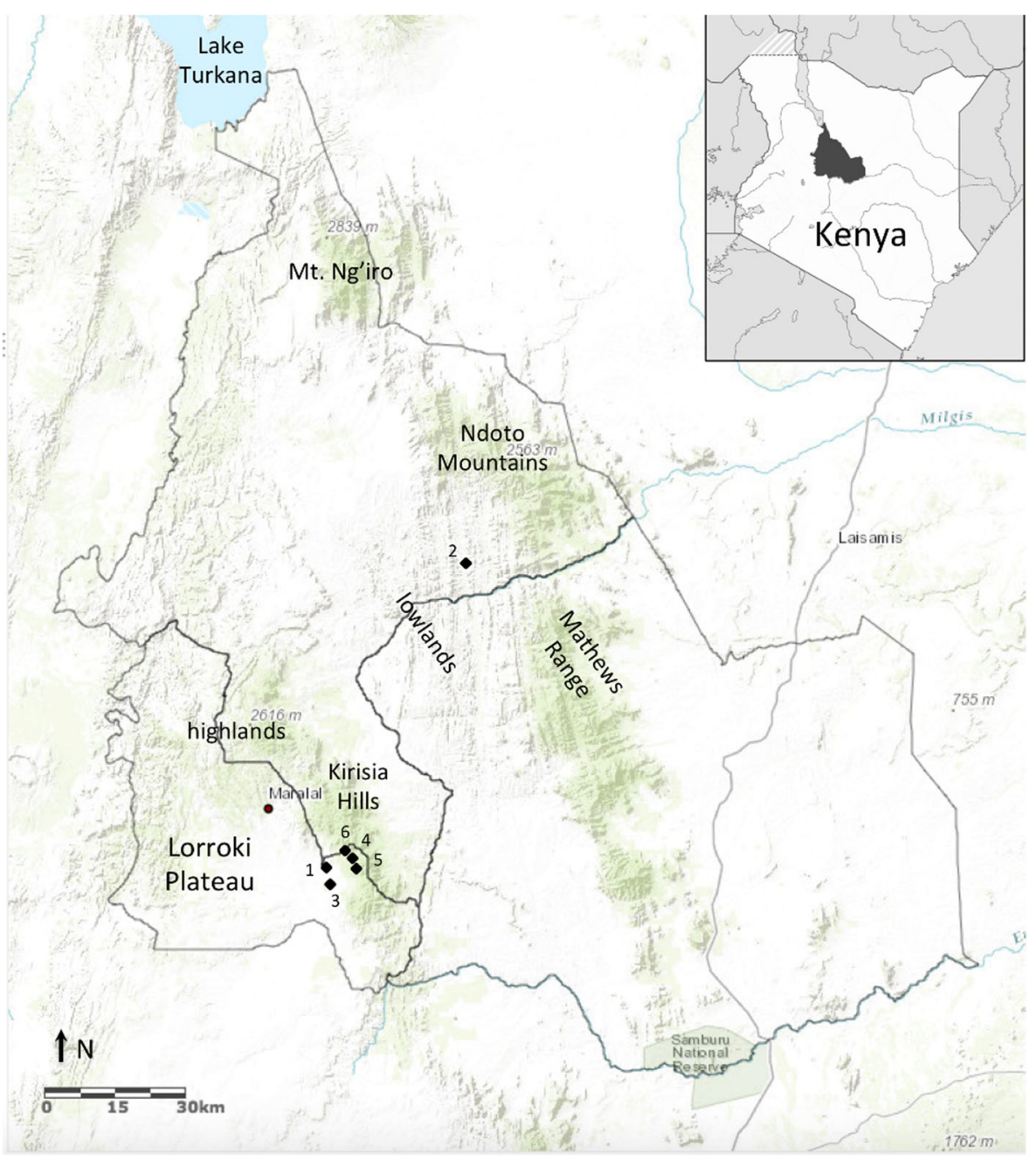

Fig. 1 Map of Samburu County, Kenya, with provenience of sampled sherds labelled (1) Naiborkeju Hill; (2) near Latakweny, lowlands; (3) Mbaringon Group Ranch, Lorroki Plateau; (4) Kikwal Rockshelter, Kirisia Hills; (5) Reprep Rockshelter, Kirisia Hills; (6) Lolmarguet Rockshelter, Kirisia Hills

highlands to the northwest, people are almost entirely sedentary and cultivate crops such as maize and beans (see Lesorogol 2008).

Holtzman (2009) notes the continuing social importance of meat in Samburu society, which is consumed primarily on ritual occasions. Cattle are central to feasts held during large lmuget circumcision ceremonies which take place at specially constructed settlements, for example, and small stock are slaughtered for other occasions including weddings or childbirth (Holtzman 2009; Grillo 2012, 2014). Food preparation and consumption in Samburu is highly formalised (Spencer 1973) and notably gendered: roasted meat is generally regarded as a masculine food, for example, and boiled meat is commonly regarded as feminine food (Holtzman 2009). These associations are not absolute; during meat feasting occasions, lmurran retreat to secluded areas such as 
rockshelters to roast and, later, make boiled soups from slaughtered cattle. In terms of wild foods, Samburu prohibit the consumption of fish, reptiles, birds, and many game animals, despite knowing they are potentially edible. Their strongest prohibition, by far, is for elephants, which they regard as similar to human beings (Holtzman 2009). Other wild fauna are only eaten in times of severe drought or other emergency. Samburu Imurran also bleed their cattle on occasions and consume the blood immediately or, more rarely, boil it with milk and fat. Women might also add small amounts of blood to soups or other boiled foods, or boil blood until it congeals. Today, though, the consumption of blood in Samburu is quite uncommon (Grillo 2012, 2014).

In terms of daily life, meat and blood are both secondary in importance to milk (kule). As Galvin $(1992 ; 212)$ writes about a number of pastoralist groups in eastern Africa, including the Samburu, Maasai and Turkana, "milk is the preferred food among all pastoral groups and is the staple when available in sufficient quantity. It is the food of choice". Milk can constitute up to $90 \%$ of calories for some pastoralists during wetter parts of the year (Little et al. 2001). Research from the early 2000s in Samburu shows that although milk now supplies only $10 \%$ of overall energy intakes (compared to $>50 \%$ from maize), it provides necessary micronutrients and is essential for childhood health (Iannotti and Lesorogol 2014b). For adults, milk in Samburu is generally prepared as tea, boiled together with water and then sweetened with sugar (Holtzman 2003). When milk is abundant it is also fermented into a thick, sour drink.

Finally, plant use and pottery, although rarely discussed, are also inextricably linked. Wild plants provide another important source of nutrition in the Samburu diet, particularly in times of drought. Although many wild plant foods can be consumed raw, the most common plants used by the Samburu are often, or always, prepared in pots (see Grillo 2012). Some plants are boiled, sometimes for long periods, to alter their consistency and make them edible or to reduce their toxicity. For example, lordo (Cyphostemma sp.) is boiled until the seeds attain a soft, porridge-like consistency. Others, such as seeds from the Balanites orbicularis, are boiled to extract their oil (Grillo 2012, 2014). Morgan (1981) also noted that Turkana pastoralists boil and reboil the fruits from several plants, including Balanites orbicularis, Balanites pedicellaris, Boscia coriacea and Dobera glabra. Pots are also sometimes used to prepare botanical medicines for treating ailments such as malaria, fever, wounds and stomach problems (Bussmann 2006).

\section{Pottery Use in Samburu}

Grillo $(2012,2014)$ conducted a year-long ethnoarchaeological study in Samburu to examine relationships between pastoralist material culture, particularly pottery, and subsistence, mobility and ideologies. Pottery in Samburu has historically been made by women from Dorobo communities, groups who identify as former hunter-gatherers but are also nonetheless deeply connected to Samburu herding communities (Brown 1989; Clarfield 1989). Today, far fewer potters make clay pots, as there is a strong stigma attached to potting and cheap metal cooking pots are now widely available instead.

Three main types of pots (moti) have been used by Samburu herders in living memory: small cooking pots (lkunate, Fig. 2a), larger cooking pots (Fig. 2d), and meat-storage pots (moti lekweshi). All cooking pots are black, globular vessels with 

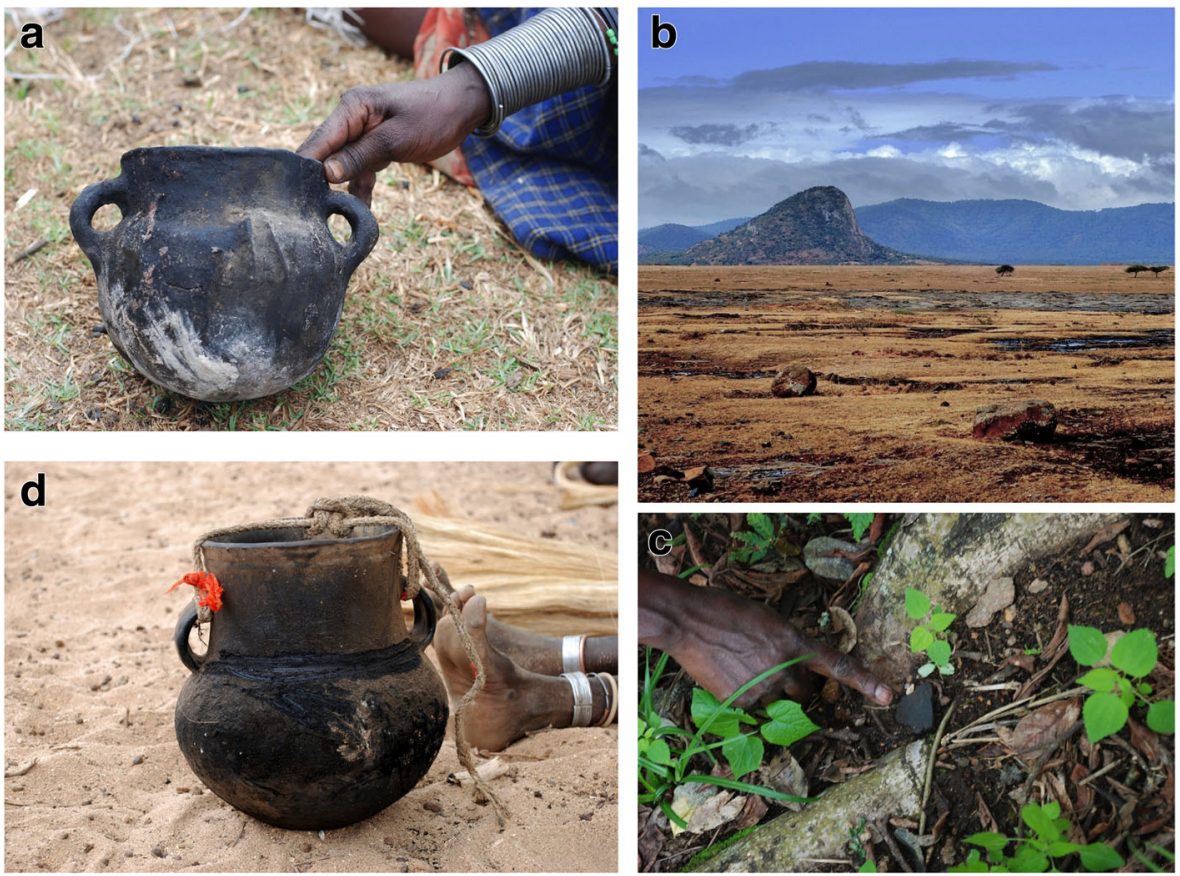

Fig. 2 a Small cooking pot (lkunate) from the Lorroki Plateau. b The Lorroki Plateau with Naiborkeju Hill and the Kirisia Hills in the distance. c A potsherd in situ at the Kikwal rockshelter. d A large cooking pot from the Samburu lowlands

handles on each side of a slightly constricted neck. Moti lekweshi are brown, handleless meat-storage pots shaped like wooden milk containers.

Blackened cooking pots are symbolically tied with the death of livestock in Samburu. They are most commonly associated today with the ceremonial slaughter of cattle, sheep and goats and the preparation of bone soups for special occasions, such as group circumcision ceremonies. In the past, lmurran also borrowed larger clay pots from their mothers' homes for cattle feasts, when they would make soups from bones, dried meat, and herbs. Elder men once owned moti lekweshi, which were pots used for storing fried strips of meat and sometimes fat, although these pots were uncommon and are thus very rarely seen in Samburu today.

In terms of day-to-day life, Samburu women and men emphasise that before the widespread availability of metal pots, clay pots had always been a dry-season technology. Smaller pots would be used for cooking seed pods and certain wild plants that would otherwise be toxic, and larger pots would be used to slow-boil bone soups when livestock were slaughtered during times with limited milk. Samburu agree that pots once allowed people to live in what can be a highly drought-prone environment by providing a means to extract maximum nutrition from the available foodstuffs when necessary. Pottery has emphatically not been associated with the processing of agricultural foods in Samburu; indeed, women are generally reluctant to use clay pots for cooking "non-pastoralist" foods, such as the now-ubiquitous maize, beans and cabbage or kale. 
Small pots (lkunate) were used to boil fresh milk for children, and during times of milk surplus, any extra might be boiled to make clarified butter or ghee. Small amounts of milk are sometimes added to soups, and also occasionally cooked with blood or seeds. Most importantly, though, milk is never collected, stored or fermented in clay pots: gourds or carved wooden "calabashes" serve those purposes instead. Samburu have had few uses for pots besides cooking foods although, as noted, occasionally smaller pots were used for preparing botanical medicines, and the few remaining lkunate in Samburu today are often curated for specific use in this way. Consequently, Grillo $(2012,2014)$ has previously speculated that lipid residue analysis would not, at least in terms of milk, reflect the relative importance of this foodstuff in Samburu diets. The present study was designed to test this assumption and to provide the first available ethnoarchaeological point of reference for lipid residue analyses of ceramic use by members of a modern-day mobile herding society.

\section{Material and Methods}

\section{Sampling of the Potsherds}

Potsherds discarded on the landscape (Fig. 2c), most likely by Samburu herders over the past several decades, were surface collected from older residential settlements and forest rockshelters during ethnoarchaeological fieldwork carried out in 2009 (Table 1). During this time, prolonged drought conditions meant that it was much easier to see surface materials normally obscured by grass cover. This specific sampling strategy was designed for two reasons. First, it would have been difficult to collect sherds from known pots directly from Samburu women themselves, as there is such a strong association with pots and the death of cattle that broken pots are swept out of view as quickly as possible. There are also taboos against handling broken pottery in certain ways, and so to avoid offence it was decided that samples should be from unknown pots, unaffiliated with current households in each area. Second, this sample more closely approximated an assemblage that might result if modern Samburu contexts were surveyed or excavated using archaeological methodologies.

Potsherds sampled were consistent in form, decoration, colour and fabric with pots made and used by Dorobo potters in recent memory and confirmed by Dorobo and Samburu elders who recognised them as such. The size of the pots is difficult to determine given that they are mostly body sherds but they clearly derive from blackened cooking pots and are made from relatively coarse fabrics. All are undecorated save for simple embossed decorations near their rims, necks or shoulders. The exact ages of the potsherds are difficult to determine; however, and it is possible (although highly unlikely) that they are associated with prehistoric pastoralist settlement in the region. The cultural/temporal provenience of sherds found on Naiborkeju (or Naibor Keju) Hill is particularly unclear. Nearby archaeological sites do include the burial site at Nakeidi cairnfield and the Baawa Pastoral Iron Age site, both on the Lorroki Plateau (Lane et al. 2007). Pottery from the cairnfield is described as thin-walled and friable, unlike Samburu sherds, and no pottery has been reported from the Baawa Pastoral Iron Age site. Pastoral Iron Age sites are also found much farther to the south on the Laikipia Plateau (Siiriäinen 1977; Causey 2010), and although a range of pottery types have 


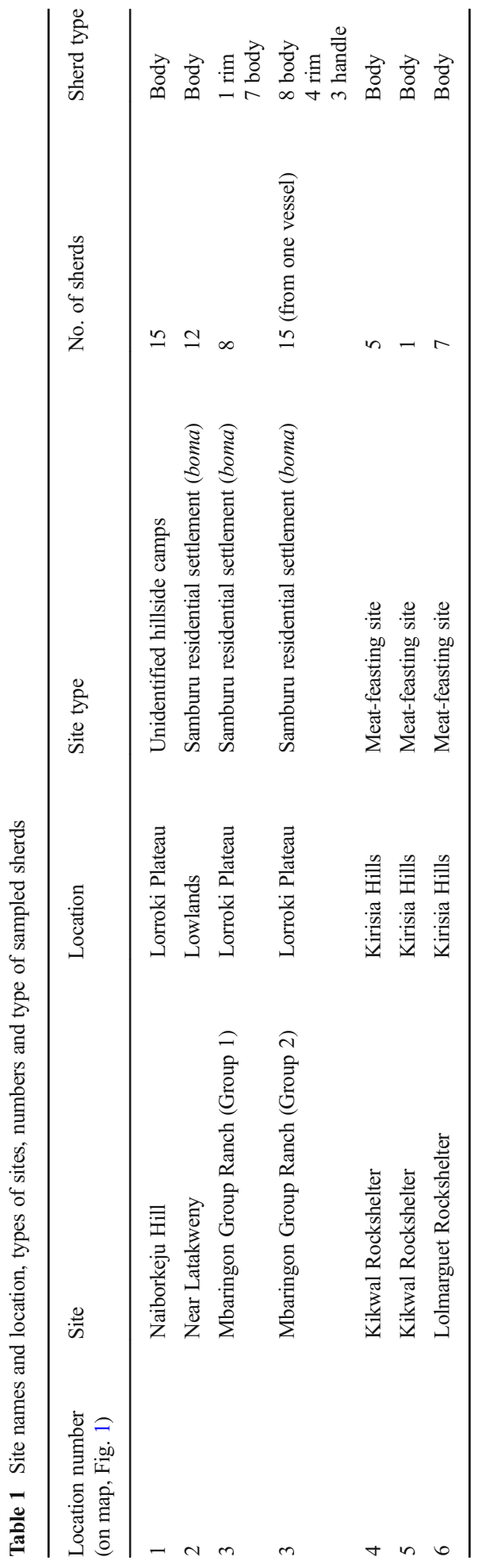


been found at those sites, some cairns do contain black, undecorated, but ultimately undiagnostic sherds (Lane et al. 2007).

For this reason, compound-specific radiocarbon dating of lipids from absorbed residues of potsherds from near Latakweny and Naiborkeju Hill was carried out to confirm the age of those sherds (Stott et al. 2003; Berstan et al. 2008; Casanova et al. under review.).

\section{Method Summary}

Lipid analysis and interpretations were performed using established protocols described in detail in earlier publications (e.g. Copley et al. 2003; Correa-Ascencio and Evershed 2014). All solvents used were HPLC grade (Rathburn), and the reagents were analytical grade (typically $>98 \%$ of purity). Briefly, $\sim 2 \mathrm{~g}$ of potsherd were sampled, and surfaces cleaned with a modelling drill to remove any exogenous lipids. The sherds were then ground to a powder and an internal standard, typically $40 \mu \mathrm{g}$, was added to enable quantification of the lipid extract ( $n$-tetratriacontane; Sigma-Aldrich Company Ltd.). Following the addition of $5 \mathrm{~mL}$ of $\mathrm{H}_{2} \mathrm{SO}_{4} / \mathrm{MeOH} 2-4 \%\left(\delta^{13} \mathrm{C}\right.$ measured), the culture tubes were placed on a heating block for $1 \mathrm{~h}$ at $70{ }^{\circ} \mathrm{C}$, mixing every $10 \mathrm{~min}$. Once cooled, the methanolic acid was transferred to test tubes and centrifuged at $2500 \mathrm{rpm}$ for $10 \mathrm{~min}$. The supernatant was then decanted into another furnace culture tube (II) and $2 \mathrm{~mL}$ of DCM extracted double-distilled water was added. In order to recover any lipids not fully solubilised by the methanol solution, $2 \times 3 \mathrm{~mL}$ of $n$-hexane was added to the extracted potsherds contained in the original culture tubes, mixed well and transferred to culture tube II. The extraction was transferred to a clean, furnaced, $3.5-\mathrm{mL}$ vial and blown down to dryness. Following this, $2 \times 2 \mathrm{~mL} n$-hexane was added directly to the $\mathrm{H}_{2} \mathrm{SO}_{4} / \mathrm{MeOH}$ solution in culture tube II and whirlimixed to extract the remaining residues. This was transferred to the $3.5-\mathrm{mL}$ vials and blown down until a full vial of $n$-hexane remained. Aliquots of the fatty acid methyl esters (FAME's) were derivatised using N,O-bis(trimethylsilyl)trifluoroacetamide (BSTFA) containing 1\% trimethyl-chlorosilane (TMCS; Sigma-Aldrich Company Ltd.; $20 \mu \mathrm{L} ; 70{ }^{\circ} \mathrm{C}, 1 \mathrm{~h}$ ). Excess BSTFA was removed under nitrogen, and the derivatised FAME was dissolved in $n$-hexane prior to GC, GC-MS and GC-C-IRMS.

The dried residue adhering to the exterior of SAM-10 was gently scraped from the surface with a solvent washed scalpel and ground to a powder using a pestle and mortar. Approximately 50\% of the powdered sample was analysed, and the remainder was stored in case required for future analysis.

All FAMEs initially underwent high-temperature gas chromatography using a gas chromatograph (GC) fitted with a high-temperature non-polar column (DB1-HT; 100\% dimethylpolysiloxane, $15 \mathrm{~m} \times 0.32 \mathrm{~mm}$ i.d., $0.1 \mu \mathrm{m}$ film thickness). The carrier gas was helium, and the temperature programme comprised a $50{ }^{\circ} \mathrm{C}$ isothermal hold followed by an increase to $350{ }^{\circ} \mathrm{C}$ at a rate of $10^{\circ} \mathrm{C} \mathrm{min}^{-1}$ followed by a $10 \mathrm{~min}$ isothermal hold. A procedural blank (no sample) was prepared and analysed alongside every batch of sherd extracts. Further compound identification was accomplished using gas chromatography-mass spectrometry (GC-MS). FAMEs were then introduced by autosampler onto a GC-MS fitted with a non-polar column (100\% dimethyl polysiloxane stationary phase; $60 \mathrm{~m} \times 0.25 \mathrm{~mm}$ i.d., $0.1 \mu \mathrm{m}$ film thickness). The instrument was a ThermoFinnigan single quadrupole TraceMS run in EI mode (electron 
energy $70 \mathrm{eV}$, scan time of $0.6 \mathrm{~s})$. Samples were run in full scan mode $(\mathrm{m} / \mathrm{z}, 50-650)$, and the temperature programme comprised an isothermal hold at $50{ }^{\circ} \mathrm{C}$ for $2 \mathrm{~min}$, ramping to $300{ }^{\circ} \mathrm{C}$ at $10^{\circ} \mathrm{min}^{-1}$, followed by an isothermal hold at $300{ }^{\circ} \mathrm{C}(15 \mathrm{~min})$. Data acquisition and processing were carried out using the HP Chemstation software (Rev. B.03.02 (341), Agilent Technologies). Peaks were identified on the basis of their mass spectra and gas chromatography (GC) retention times, by comparison with the NIST mass spectral library (version 2.0).

Carbon isotope analyses by GC-C-IRMS were also carried out using a GC Agilent Technologies 7890A coupled to an Isoprime 100 (EI, $70 \mathrm{eV}$, three Faraday cup collectors $\mathrm{m} / \mathrm{z}, 44,45$ and 46) via an IsoprimeGC5 combustion interface with a $\mathrm{CuO}$ and silver wool reactor maintained at $850{ }^{\circ} \mathrm{C}$.

The software OxCal v4.3 was used to calibrate the radiocarbon measurement using the calibration curve Bomb13NH3 for the pot SAM10 and the calibration curve IntCal13 for the two other pots (SAM14-6 and SAM15-3).

\section{Results and Discussions}

A total of 63 potsherds, collected from various locations in the Samburu district (Fig. 1 and Table 1), and a section of thickly encrusted residue found covering the exterior of one vessel (SAM10), were analysed. The rate of lipid recovery (of interpretable residues) was $48 \%$, and the mean lipid concentration of the sherds was $8.3 \mathrm{mg} \mathrm{g}^{-1}$, with a maximum lipid concentration of $64.9 \mathrm{mg} \mathrm{g}^{-1}$ (Table 2). This study sheds additional light on the potential for sherds to absorb lipid, for example, the maximum concentration of absorbed lipid we have ever observed in an archaeological potsherd, from Christian (AD 600-1500) phases of occupation of the site of Qasr Ibrm, Egyptian Nubia, is $17.8 \mathrm{mg} \mathrm{g}^{-1}$ (Copley et al. 2005), whilst a further potsherd from Middle Pastoral Levels (ca. 5200-3800 BC) at Takarkori rockshelter, Libya, displayed a concentration of $17.2 \mathrm{mg} \mathrm{g}^{-1}$ (Dunne et al. 2012). It has long been known that all residues are subject to a degree of degradative loss during burial, and, consequently, previous experimental work has focussed on the maximum capacity of potsherds to absorb lipids, recording maximum mean values from vessels used to repeatedly boil lamb of $21.8 \mathrm{mg} \mathrm{g}^{-1}$ and containing olive oil, $13.5 \mathrm{mg} \mathrm{g}^{-1}$ (Aillaud 2001). However, here, we note several extremely high concentrations of lipids (Table 2) at 21.1, 14.6, $35.0,64.9,26.0,18.9$ and $52.6 \mathrm{mg} \mathrm{g}^{-1}$. These analyses of ethnographic pottery, used in recent history, suggest that the potential for sherds to absorb lipids over the life history of a vessel use is considerably higher than previously thought, possibly relating to the porosity of varying clay fabrics. Furthermore, it confirms that at least three of these Samburu pots were likely used for intensive processing of animal products.

Analysis of the FAMEs extracted from the Samburu potsherds demonstrates that the free fatty acids, palmitic $\left(\mathrm{C}_{16: 0}\right)$ and stearic $\left(\mathrm{C}_{18: 0}\right)$ are the most abundant components. Odd numbered fatty acids $\left(\mathrm{C}_{15: 0}\right.$ and $\left.\mathrm{C}_{17: 0}\right)$ are also present, possibly indicative of a bacterial origin, resulting from microbial activity in the rumen, characteristic of a ruminant fats origin (Evershed et al. 2002). However, no other compounds, such as $n$-alkanes denoting plant processing, were present. Compounds denoting the presence of waxes, resins or bitumen, which might suggest post-firing treatment of vessels (for sealing), were also absent. 


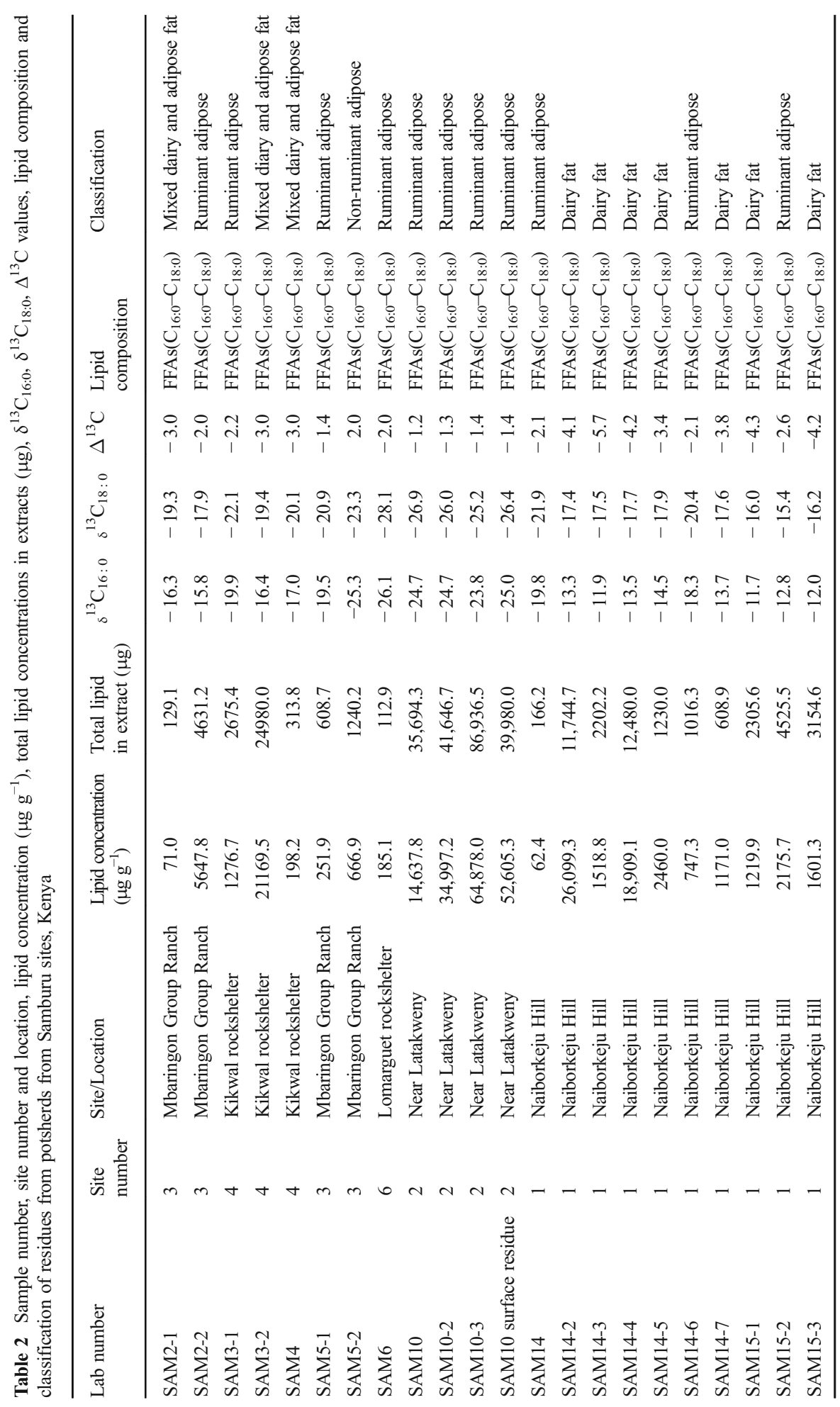




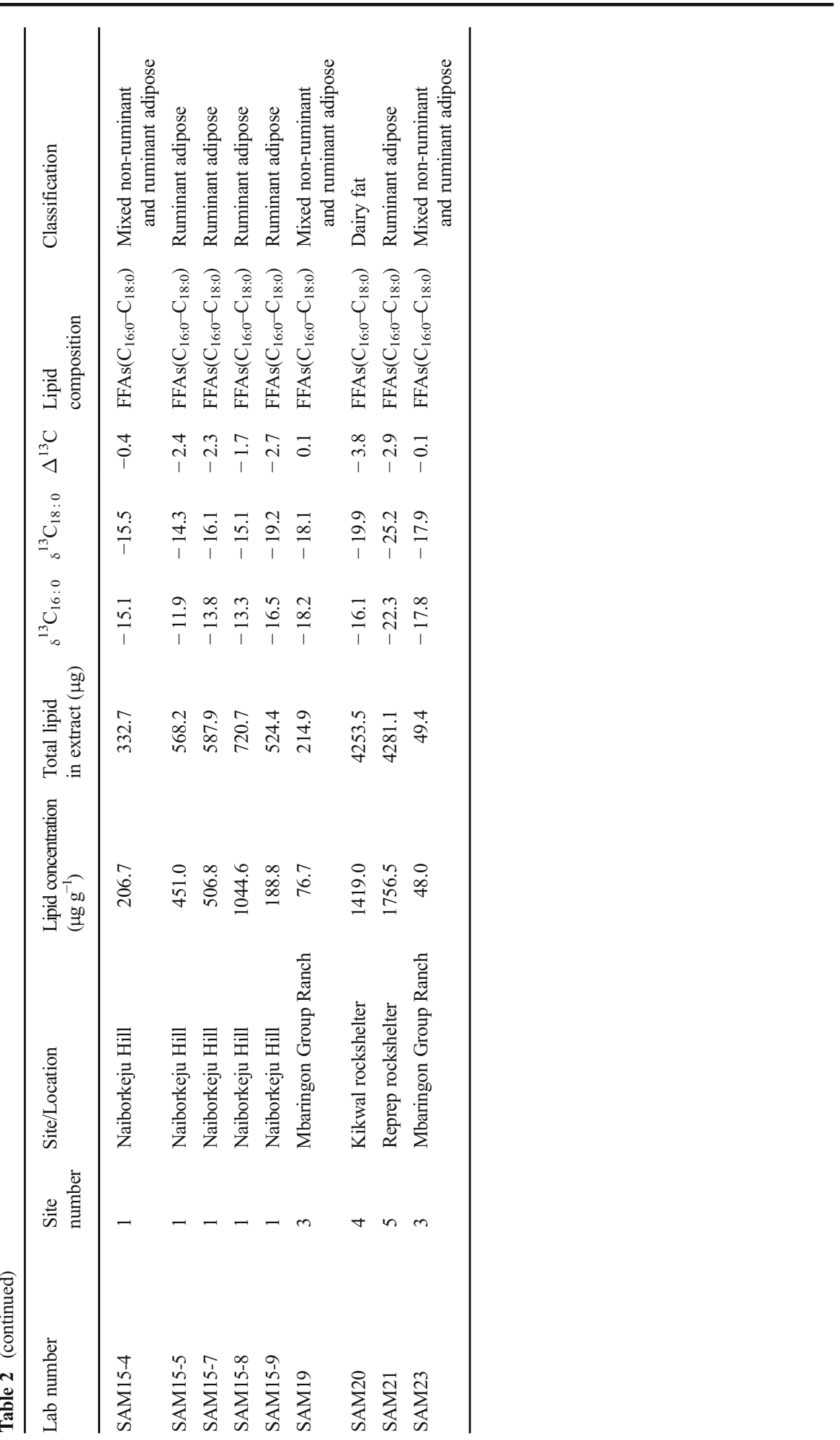


GC-C-IRMS analyses were carried out on 31 FAMEs (from 30 potsherds and one surface residue) to determine the $\delta^{13} \mathrm{C}$ values of the major fatty acids, $\mathrm{C}_{16: 0}$ and $\mathrm{C}_{18: 0}$, and ascertain the source of the animal fats extracted from the Samburu residues using the $\Delta^{13} \mathrm{C}$ proxy (Figs. 3 and 4 and Table 2). Differences occur in the $\delta^{13} \mathrm{C}$ values of these major $n$-alkanoic acids, palmitic $\left(\mathrm{C}_{16: 0}\right)$ and stearic $\left(\mathrm{C}_{18: 0}\right)$ due to the differential routing of dietary carbon and fatty acids during the biosynthesis of adipose and dairy fats in ruminant animals, thus allowing ruminant milk fatty acids to be distinguished

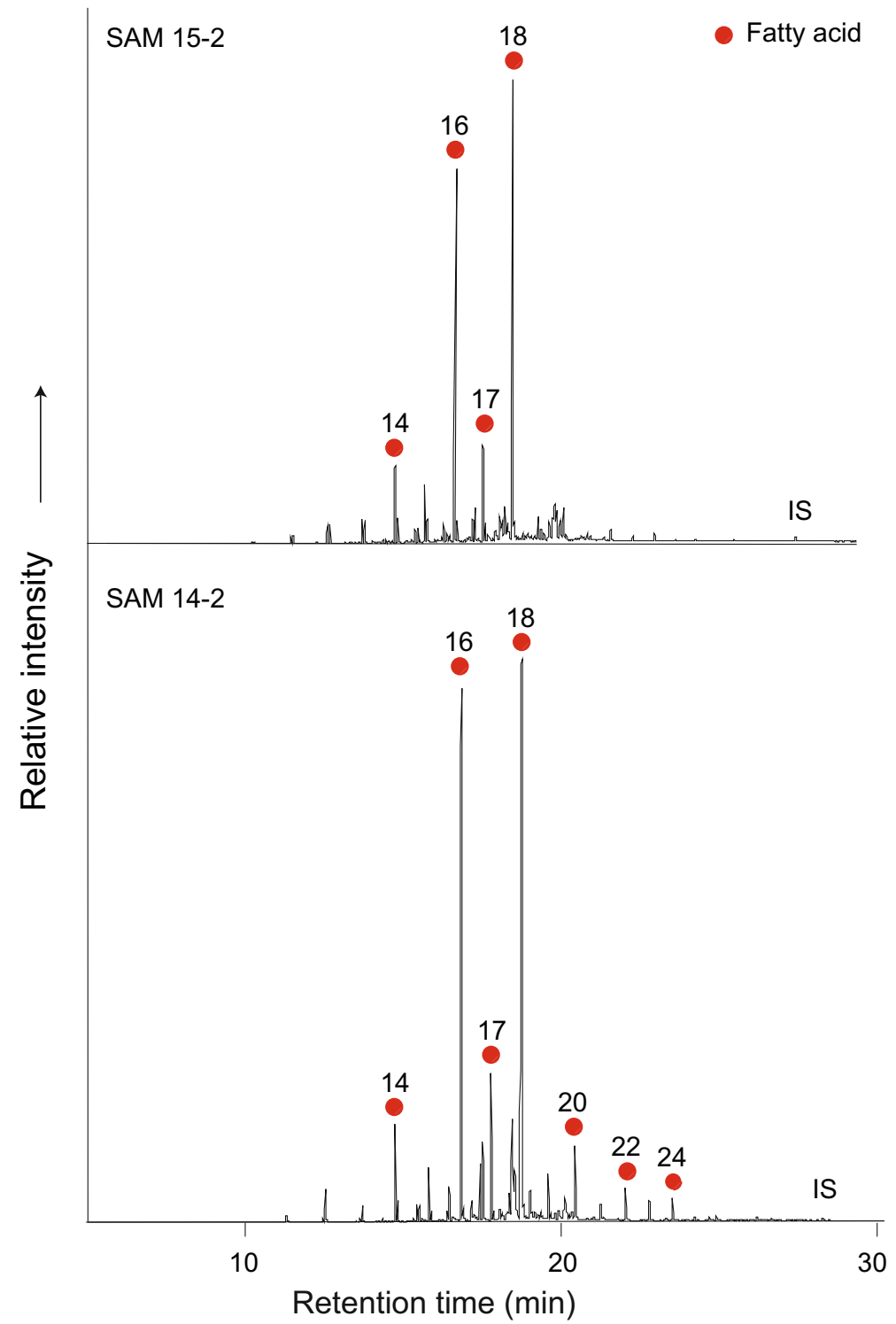

Fig. 3 Typical chromatograms of FAME TLEs from Samburu, Kenya, showing typically degraded animal fat profiles (SAM 14-2 AND SAM 15-2), one with a sequence of long-chain fatty acids. FAx are fatty acids where $\mathrm{x}$ is the carbon chain length; IS internal standard, $n$-tetratriacontane $\left(n-\mathrm{C}_{34}\right)$ 

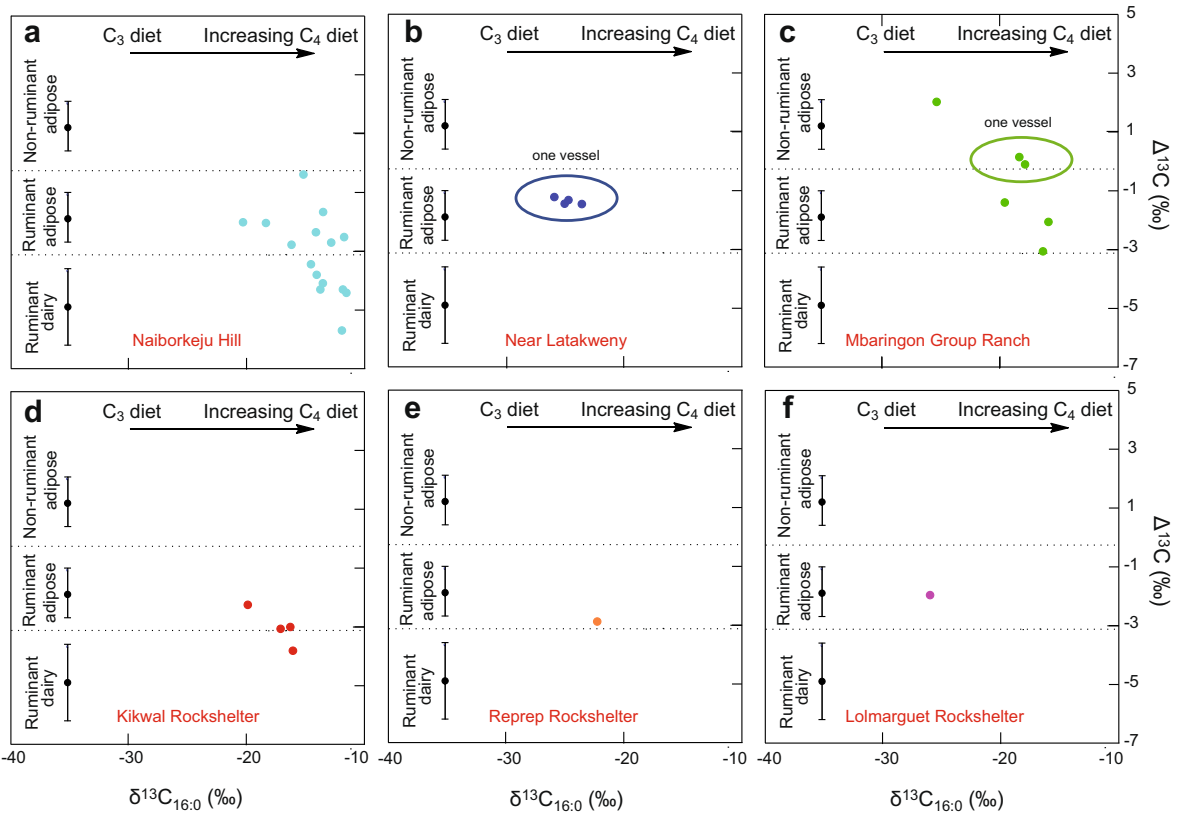

Fig. 4 Graphs (a-f) showing the $\Delta^{13} \mathrm{C}\left(\delta^{13} \mathrm{C}_{18: 0}-\delta^{13} \mathrm{C}_{16: 0}\right)$ values from the Samburu potsherds by site. The ranges shown here represent the mean \pm 1 s.d. of the $\Delta^{13} \mathrm{C}$ values for a global database comprising modern reference animal fats from Africa (Dunne et al. 2012), UK (animals raised on a pure C3 diet) (Dudd and Evershed 1998), Kazakhstan (Outram et al. 2009), Switzerland (Spangenberg et al. 2006) and the Near East (Gregg et al. 2009), published elsewhere

from carcass fats by calculating $\Delta{ }^{13} \mathrm{C}$ values $\left(\delta^{13} \mathrm{C}_{18: 0}-\delta^{13} \mathrm{C}_{16: 0}\right)$ and plotting that against the $\delta^{13} \mathrm{C}$ value of the $\mathrm{C}_{16: 0}$ fatty acid. Previous research has shown that by plotting $\Delta \Delta^{13} \mathrm{C}$ values, variations in $\mathrm{C}_{3}$ versus $\mathrm{C}_{4}$ plant consumption are removed, thereby emphasising biosynthetic and metabolic characteristics of the fat source (Dudd and Evershed 1998; Copley et al. 2003; Dunne et al. 2012). Furthermore, the foods that animals eat exhibit characteristic isotopic signatures (Gannes et al. 1997), and isotopic analyses $\left(\delta^{13} \mathrm{C}\right)$ of fatty acids extracted from archaeological potsherds are thus a reflection of the consumed diet, providing information about the environment in which the animals foraged (Copley et al. 2003; Mukherjee et al. 2005).

Here, the $\delta^{13} \mathrm{C}_{16: 0}$ values of the fatty acids extracted from the Samburu potsherds range from -26.1 to $-11.7 \%$, and the $\delta^{13} \mathrm{C}_{18: 0}$ values range from -28.1 to $-14.3 \%$ o (Table 2). It is noteworthy that some of the $\delta^{13} \mathrm{C}_{16: 0}$ values from the Samburu lipid residues are even more enriched than African reference fats, e.g. SAM15-1 at-11.7\%o, notably the most enriched modern animal fats collected from Kenya, at $-13.9 \%$ o (Dunne et al. 2012). In particular, fatty acid carbon isotope values from the Naiborkeju Hill sherds suggest a heavy reliance on $\mathrm{C}_{4}$ plants, possibly suggesting the pottery was used to cook animal products during periods of extreme drought, where the animals would have only had access to arid-adapted vegetation. The range of $\delta^{13} \mathrm{C}_{16: 0}$ values from the other sites seem to be as constrained (aside from Mbaringon Group Ranch where the residue with the most contribution from $\mathrm{C}_{3}$ plants seems to originate from a wild faunal source). This limited range raises questions as to how mobile these pastoralists' animals are - do the residues just reflect different vegetation types in 
locations where animals are being herded but not moved long distances? The sherds from the Latakweny vessel, with a ruminant adipose origin, also display a significant $\mathrm{C}_{3}$ contribution, although it is difficult to make meaningful interpretations based on one vessel.

\section{Near Latakweny}

Three potsherds (from the same vessel) found close to Samburu residential settlements near Latakweny in the lowlands, SAM10, SAM10-2 and SAM10-3, yielded the highest known concentrations of absorbed lipid observed to date at $14.6,35.0$ and $64.9 \mathrm{mg} \mathrm{g}^{-1}$, respectively. It is not known which part of the vessel the sherds originate from but it may be these come from points near the base, middle and rim of the vessel ( $c f$ Charters et al. 1993). These plotted firmly within the ruminant adipose section (Fig. 4b), with $\Delta^{13} \mathrm{C}$ values of $-1.2,-1.3$ and $-1.4 \%$ o, respectively. The $\delta^{13} \mathrm{C}_{16: 0}$ values are -24.7 , -24.7 and $-23.8 \%$ o, respectively, suggesting the animals producing these fats subsisted on a predominantly $\mathrm{C}_{3}$ diet with some $\mathrm{C}_{4}$ input. Despite concerns for the potential of external organic residues to become affected by post-burial or post-excavation contamination (Evershed 2008a), due to their exposed nature, the thickly encrusted residue preserved on the outside of the vessel SAM10 was analysed in order to make comparisons between the absorbed and external (surface) residues. Significantly, the concentration of the external residue was extremely high, at $52.6 \mathrm{mg} \mathrm{g}^{-1}$, perhaps not surprising as the absorbed residues also displayed extremely high concentrations of the lipids. The $\Delta^{13} \mathrm{C}$ value of this surface residue was $-1.4 \%$, which agrees well with the $\Delta^{13} \mathrm{C}$ values of the absorbed lipids. These concentrations suggest that this vessel was clearly intensively used to boil ruminant animal products, possibly over a prolonged period. Compound-specific radiocarbon dating of the absorbed residues from potsherd SAM10 confirms the ethnographic attribution of this vessel, at between 2002 and 2004 AD (BRAMS 1594; 95.4\% probability).

\section{Mbaringon Group Ranch}

Of the eight potsherds (and a further 15 from one individual pot, groups 1 and 2, respectively, Table 1) collected from close to Samburu residential settlements at the Mbaringon Group Ranch on the Lorroki Plateau, six yielded interpretable lipid profiles, displaying a broad range of $\delta^{13} \mathrm{C}$ and $\Delta^{13} \mathrm{C}$ values, although it should be noted that two sherds were from the same vessel (Fig. 4). One of the residues, SAM5-2, plots within the range for non-ruminant adipose fats at $2.0 \%$. This is the only residue in the dataset that originates from a non-ruminant source and is surprising as the Samburu do not routinely hunt or consume wild game, indeed, as mentioned, there are dietary restrictions on the consumption of many types of wild fauna. However, during times of scarcity or famine, the Samburu will consume wild animals, preferably those that bear the closest relation to domesticated species, such as eland, buffalo and antelope (Holtzman 2009). As these species are also ruminants, as are many of the game animals found across Kenya, it is difficult to hypothesise what species of non-ruminant animals might have been processed in this vessel. Of the four remaining lipid profiles, SAM5-1 $(-1.4 \% o)$ and SAM2-2 $(-2.0 \%$ ) plot firmly within the ruminant adipose range. SAM19 $(0.1 \%$ ) and SAM23 $(-0.1 \%$ o), from the same vessel, plot on the border 
between ruminant and non-ruminant adipose fats, suggesting some mixing between the two, and similarly, SAM2-1 $(-3.0 \%$ ) plots very closely to the borderline between ruminant adipose and ruminant dairy fats, again implying some mixing of these fats occurred within the pot, either contemporaneously or during its lifetime use. The $\delta^{13} \mathrm{C}_{16: 0}$ values of these animal products range between -25.3 and $-15.8 \%$, respectively. These data from the Mbaringon potsherds suggest a significant contribution of $\mathrm{C}_{4}$ plants to the diet of the animals producing these fats, aside from the sample SAM5-2 which has a more $\mathrm{C}_{3}$ origin.

\section{Naiborkeju Hill}

A series of 15 potsherds were collected from unidentified contexts on the side of Naiborkeju Hill on the Lorroki Plateau. These all yielded lipid residues, often with high concentrations, e.g. SAM14-2, SAM14-4, SAM15-2 and SAM15-3 at 26.1, 18.9, 2.2 and $1.6 \mathrm{mg} \mathrm{g}^{-1}$, respectively (Table 2). One of the sherds, SAM15-4, displayed a $\Delta^{13} \mathrm{C}$ value of $-0.4 \%$, plotting on the borderline between ruminant and non-ruminant adipose fats. This is very similar to the value obtained from sherds SAM19 (0.1\%o) and SAM23 (-0.1\%o) (from a vessel sampled at Mbaringon Group Ranch) where some processing of wild game is indicated. Six of the Naiborkeju sherds plotted within the ruminant adipose range (SAM14, SAM14-6, SAM15-2, SAM15-5, SAM15-7, SAM15-8 and SAM15-9, at $-2.1,-2.1,-2.6,-2.4,-2.3,-1.7$ and $-2.7 \%$, respectively, Fig. 4a), and the remaining seven plotted within the ruminant dairy range (SAM14-2, SAM14-3, SAM14-4, SAM14-5, SAM14-7, SAM15-1 and SAM15-3 at $-4.1,-5.7,-4.2,-3.4,-3.8,-4.3$ and $-4.2 \%$, respectively, Fig. $4 a)$, confirming that dairy products were processed in these vessels. This is particularly surprising as it is known that the Samburu do not collect or store milk in clay pots, and only rarely boil milk or prepare ghee in pots. Interestingly, these lipid residues have much higher abundances in comparison to the vessels used to process carcass fats. In terms of herd management practices, the animals producing the dairy fats subsisted on a wholly $\mathrm{C}_{4}$ diet since the $\delta^{13} \mathrm{C}_{16: 0}$ values ranged from -13.5 to $-11.9 \%$. In contrast, the animals producing the carcass fats, with $\delta{ }^{13} \mathrm{C}_{16: 0}$ values ranging from -21.9 to $-14.3 \%$, subsisted on a broader range of forages, although still primarily within the $\mathrm{C}_{4}$ range. This suggests the animals producing these fats may have been managed differently by these earlier pastoralists; for example, the dairy animals may have been kept close to the settlement, perhaps as a milk herd, and foddered on $\mathrm{C}_{4}$ plants, whereas the animals exploited for their carcass products may have been more mobile.

Naiborkeju Hill is a socially and symbolically important place on the Samburu landscape, and some oral traditions recall Naiborkeju as a place of refuge for members of Laikipiak Maasai clans that were defeated by Samburu in the nineteenth century (see Straight 2008). Its slopes do contain numerous examples of rock art and scatters of archaeological material (Chamberlain 2006). Today, there are no groups living directly on the hillslopes at Naiborkeju, nor have people used the hillslopes for encampments or feasting sites in recent memory. Thus, it is unclear who might have been bringing the pottery sampled at Naiborkeju to this hill. The fact that these signatures are so qualitatively different from those sherds found at the rockshelter sites, and the settlement sites might suggest that perhaps these sherds are significantly older than the other sampled sherds, and that patterns of pottery use amongst pastoralists may have changed 
significantly in this region through time. To test this hypothesis, compound-specific radiocarbon dating was carried out on absorbed residues from two potsherds, one containing ruminant adipose products (SAM14-6), and the other, dairy products (SAM15-3). Both dates are pre-1950 (BRAMS1596 and 1597: uncalibrated ages of $171 \pm 22$ and $122 \pm 22 \mathrm{BP}$, respectively). However, it should be noted that the part of the calibration curve where the data are plotted presents as a plateau, and thus, the age of the potsherds likely falls within the range of the seventeenth to twentieth centuries (probabilities as follows: 1670-1697 AD (15.2\%), 1725-1780 AD (36.8\%), 17961814 AD (11.8\%), 1835-1878 AD (11.5\%) and 1916-1944 AD (20.1\%)). The Lorroki Plateau had indeed been occupied throughout this span by ethnically and economically fluid groups of both hunter/gatherer communities and Maa-language-speaking pastoralists (Larick 1986; Lane 2011).

Here, our recently developed technique which utilises compound-specific dating of absorbed lipids from pottery has provided an explanation for these seemingly anomalous lipid residue results. Earlier pastoralists living in the area, or hunter/gatherers with access to livestock and/or milk, used their pottery to process dairy and ruminant carcass products in almost equal measure. This apparent change in culinary practice among peoples in the region demonstrates how substantial shifts in either patterns of food consumption or ceramic use can occur over a relatively short period of time, perhaps as little as 100-200 years, which, in many cases, might be difficult to detect over archaeological timescales.

\section{Reprep, Kikwal and Lolmarguet Rockshelters}

Potsherd SAM21 collected from the Reprep rockshelter in the Kirisia Hills, a small meatfeasting site, displayed a $\Delta^{13} \mathrm{C}$ value of $-2.9 \%$ and plots at the lower end of the range for ruminant animal product processing (see Fig. 4e). The $\Delta^{13} \mathrm{C}$ values of the four potsherds (SAM3-1, SAM3-2, SAM4 and SAM20, Fig. 4d) from another meat-feasting site, the Kikwal rockshelter, that yielded lipids $(4 / 5 ; 80 \%$ recovery) are $-2.2,-3.0,-3.0$ and $-3.8 \%$, respectively. Of these, SAM3-1 plots firmly within the ruminant adipose range, SAM3-2 and SAM4 plot on the borderline between ruminant carcass and dairy fats, and SAM20 plots in the ruminant dairy range. Ruminant dairy fats are differentiated from ruminant adipose fats when they display $\Delta^{13} \mathrm{C}$ values of less than $-3.1 \%$ o (Dunne et al. 2012; Salque 2012). The results for SAM20 (dairy product processing) are again somewhat unexpected, although it is known that pottery is often taken from the homes of Samburu mothers to use at meat-feasting sites. It may be that this pot, although mainly used to cook meat and bone soups, may have also been used to process milk/ghee and was taken to be used at a meat-feasting site and broken shortly after. Sample SAM6 was collected from the Lolmarguet rockshelter, known to have been used for meat feasting by the Dorobo community in living memory. This plots firmly within the ruminant adipose range $(-2.0 \%$, Fig. $4 \mathrm{f})$. These data confirm that the pottery used at these meat-feasting sites was indeed, as expected, primarily used to extensively boil meat.

\section{Conclusion}

In summary, we present a suite of data comprising molecular and isotopic signatures on sherds collected from different use-contexts in a pastoralist society in which we know, 
ethnographically, exactly how their subsistence system was structured, and how ceramics were used both in everyday and exceptional times. Consequently, these data from Samburu pottery reflect the entire use-lives of pots as employed in a single ethnographic context and thus provide important baseline reference data for understanding the origins and development of mobile pastoralism throughout Africa as reconstructed through ceramic residue studies. For example, forthcoming research will examine Pastoral Neolithic pottery use in eastern Africa, where ceramic function has thus far been largely ignored ( $c f$ Ashley and Grillo 2015) despite its relevance to our understanding of, for example, both pastoralist adaptions to new environments and instances of pastoralist-forager cultural contact. These Samburu findings also provide a comparative frame of reference for interpreting diet and subsistence practices in different food-producing economies on broader scales.

Significantly, though, these results raise real concerns over how archaeologically recovered lipid residues are interpreted in the literature on ancient food systems. How do these residues evince either broader subsistence practices or the day-to-day realities of culinary practice? The results from Samburu pottery confirm ethnoarchaeologically derived assumptions that lipid residues would not, for example, reflect the relative importance of different foodstuffs to Samburu pastoralists - in terms of their daily consumption. Most of the $\Delta^{13} \mathrm{C}$ values from Samburu pots suggest that vessels were intensively used to process ruminant carcass products, yet the Samburu economy is not, in fact, meat-based at all. Milk, instead, has been the staple food in Samburu in longterm memory. Significantly, however, the lipid compositions do reflect the ideological importance of meat/fat, which are the culinary centre of the Samburu social and ceremonial universe (Holtzman 2009). It also appears that the use of pots to cook meat during ceremonies and meat feasting obscures residual signatures from all other Samburu foods processed in clay pots (wild plant foods and medicines, for example, along with occasional milk). These results thus serve as a salutary reminder that certain foodstuffs may often/always be "hidden" in terms of lipid residue analysis and highlight the difficulty of examining plant consumption-largely invisible in pottery residues, particularly in prehistory. To date, only one case is known of lipid distributions denoting plant consumption, in prehistoric Saharan pottery, where $n$-alkanes indicate the presence of plant leaf waxes and specific fatty acid distributions suggest the processing of plant oils (Dunne et al. 2016). Significantly, vessels from the early to middle Holocene sites of Takarkori and Uan Afuda, Libya, were clearly used specifically for plant processing, whereas experiments have shown that if meat and plants were processed in the same vessel, the meat signal would "swamp" the plant signal (Evershed et al. 1991; Charters et al. 1997; Evershed 2008a). We also regard as suspect identifications of commodities such as herbs and spices in the literature as these are trace components and will likely be undetectable.

The fact that no sampled sherds from either settlement or meat-feasting sites (aside from Naiborkeju Hill, and one sherd from Kikwal rockshelter) show evidence for dairy product processing also serves as a reminder that ceramic use - or the use of any other tool-is often as much a matter of (idiosyncratic) cultural choice as a reflection of technological necessity ( $c f$. Lemmonier 1986). Milk, the dietary staple of Samburu, as among many other eastern African pastoralist groups, is generally not cooked or stored in pots at all. However, the initially puzzling results from Naiborkeju Hill which implied a roughly equal reliance on meat $/$ milk products were resolved once 
compound-specific radiocarbon dating was carried out on absorbed residues from two of the potsherds (Stott et al. 2003: Berstan et al. 2008, Casanova et al., under review). This dating demonstrated that these sherds were likely older than the remainder of the modern-day ethnographic pottery analysed, which is consistent with interview data on local uses of these particular landscapes.

In many respects, this combined ethnoarchaeological and scientific approach to the study of modern Samburu pottery is a cautionary tale, suggesting that lipid residues in ceramic vessels cannot (uncritically) be used as proxies for the overall subsistence economies of past communities. Nor, as this pastoralist case study reveals, do lipid residues necessarily reflect the full range of complex daily, gendered, and specialoccasion practices that comprise a society's food system. Aside from large-scale studies (e.g. the ERC funded NeoMilk project or our Leverhulme funded "Peopling the Green Sahara" project) we argue that the lipid residue record, similar to the archaeological record itself, is unlikely to be either complete or comprehensive and probably represents "snapshots" of dietary practices, possibly over short timescales. The complex human choices involved in the selection, preparation and consumption of foodstuffs are intimately related to different social ties and identities, as is well-established in the ethnoarchaeological literature (Hodder 1982). Yet these choices remain largely unknowable from lipid residues alone. Furthermore, we argue that tackling "big questions" about the past - such as those related to transitions to pastoralism and/or crop agriculture in Africa, and the complex social and cultural factors associated with them-will require an array of techniques drawn from both archaeological science and social archaeology.

These findings also suggest that there is little value in small-scale lipid residue studies where very limited numbers of sherds are studied, e.g. less than 30 per chronological phase or vessel type, generally regarded as the minimum needed to produce a statistically reliable result (Historic England 2017). Such small-scale studies are too commonplace in the literature (with some studies based on fewer than 10 sherds), and we propose that they will certainly not reflect the true picture of dietary practices in an ancient community. The sampling and residue analysis of particular vessel shapes or forms from an assemblage, thought to be used in food processing, may well reflect everyday use but might equally relate to some specific food processing practices, perhaps for social or ritual purposes, consequently not providing a true representation.

Furthermore, questions must always be asked about the level of resolution that can be obtained from such studies. Our results demonstrate that interpretations of a small assemblage from a chronological phase may only be representative of dietary practices during timeframes as small as a generation. Furthermore, we should note that human behaviour is invariably complex and often arbitrary, and people in the past may have been very fluid and flexible in their responses to both short- and long-term changes in their wider environment. For example, in times of great ecological stress, cultural prohibitions/ideologies may well have been set aside, although these behaviours may only be short-lived. Consequently, small-scale lipid residue studies cannot be regarded as representative (as often claimed) of either particular culinary choice or dietary practices over long time periods. In this instance, we have demonstrated that vessels sampled may not reflect the dominance of use of the main commodity exploited by the Samburu, milk, but rather reveals the ideological importance of meat/fat, which is the culinary centre of the Samburu social and ceremonial universe. 
The value of lipid residue analyses, rather, lies in large scale or diachronic analyses providing broader perspectives on the uses of pottery over chronological and spatial spheres. We urge future analysts to sample a wide range of depositional contexts across archaeological landscapes (open-air sites, rockshelters, etc.) to provide a more comprehensive picture of ceramic use at any given point in time. We also emphasise the critical importance of interpreting lipid residue results in conjunction with other archaeological information, such as faunal and archaeobotanical evidence, to gain, as far as possible, a comprehensive and balanced picture of past dietary practices. In doing so, archaeologists can begin to consider the myriad ways that changes in the use of pottery mightor might not - reflect changes in the social, economic and ideological dynamics of past communities through time. Additional ethnoarchaeological data on modern foodways, as they very specifically relate to material culture, would likewise productively broaden our frames of reference for future lipid residue studies.

Acknowledgements The authors wish to thank the Natural Environment Research Council (NERC) for partial funding of the mass spectrometry facilities at the University of Bristol (contract no. R8/H10/63; www. 1smsf.co.uk), The Leverhulme Trust (RPG-2016-115), the European Research Council (ERC) Advanced Grant NeoMilk (FP7-IDEAS-ERC/324202) attributed to Richard P. Evershed, the National Science Foundation (grant number 0752042), the Wenner Gren Foundation for Anthropological Research, the Ministry of Science and Education and the National Museums of Kenya. KG would like to thank Prame Lesorogol, Carolyn Lesorogol, Lolkitari Lesorogol and the many other women and men of Samburu who assisted during this fieldwork. JD would like to thank Ian Bull and Alison Kuhl for technical help. We thank Tim Knowles of the Bristol Radiocarbon Accelerator Mass Spectrometry Facility (BRAMS) for radiocarbon dating of potsherds, Mary Prendergast for assistance with Fig. 1 and Helen Grant of the Natural Environment Research Council Life Sciences Mass Spectrometry Facility (Lancaster node) for stable isotopic characterisation of reference standards and derivatising agents. Finally, the authors would like to thank the reviewers for their helpful and constructive comments on our earlier draft of this paper.

Author Contribution The project was designed by KG, and the paper was written by JD and KG. KG conducted ethnographic research and collected samples. JD, HLW and EC performed analytical work and data analysis. RPE was involved in the planning and interpretation of the organic residues analyses and writing the paper laboratory director. All authors read and approved the final manuscript.

Open Access This article is distributed under the terms of the Creative Commons Attribution 4.0 International License (http://creativecommons.org/licenses/by/4.0/), which permits unrestricted use, distribution, and reproduction in any medium, provided you give appropriate credit to the original author(s) and the source, provide a link to the Creative Commons license, and indicate if changes were made.

\section{References}

Aillaud, S. (2001). Field and laboratory studies of diagenetic reactions affecting lipid residues absorbed in unglazed archaeological pottery vessels. Unpublished $\mathrm{PhD}$ thesis, University of Bristol.

Ashley, C. Z., \& Grillo, K. M. (2015). Archaeological ceramics from eastern Africa: past approaches and future directions. Azania: Archaeological Research in Africa, 50(4), 460-480.

Beck, C. W., Smart, C. J. and Ossenkop, D. J. (1989). Residues and linings in ancient Mediterranean transport amphoras. In R. O. Allen, (Ed.), Archaeological Chemistry, vol. 4 (pp. 369-380). Advances in Chemistry Series 220. Washington, D.C.: American Chemical Society.

Berstan, R., Stott, A. W., Minnitt, S., Ramsey, C. B., Hedges, R. E. M., \& Evershed, R. P. (2008). Direct dating of pottery from its organic residues: new precision using compound-specific carbon isotopes. Antiquity, 82(317), 702-713. 
Brettell, R. C., Stern, B., Reifarth, N., \& Heron, C. (2014). The 'semblance of immortality'? Resinous materials and mortuary rites in Roman Britain. Archaeometry, 56(3), 444-459.

Brettell, R. C., Schotsmans, E. M. J., Walton Rogers, P., Reifarth, N., Redfern, R. C., Stern, B. \& Heron, C. P. (2015). 'Choicest unguents': molecular evidence for the use of resinous plant exudates in late Roman mortuary rites in Britain. Journal of Archaeological Science, 53, 639-648.

Brown, J. (1989). Samburu Dorobo (Mathews). In J. Barbour \& S. Wandibba (Eds.), Kenyan pots and potters (pp. 77-80). Nairobi: Oxford University Press.

Brown, K. M., Connan, J., Poister, N. W., Vellanoweth, R. L., Zumberge, J., \& Engel, M. H. (2014). Sourcing archaeological asphaltum (bitumen) from the California Channel Islands to submarine seeps. Journal of Archaeological Science, 43, 66-76.

Buckley, S. A., Clark, K. A., \& Evershed, R. P. (2004). Complex organic chemical balms of Pharaonic animal mummies. Nature, 431(7006), 294-299.

Bussmann, R. (2006). Ethnobotany of the Samburu of Mt. Nyiru, South Turkana, Kenya. Journal of Ethnobiology and Ethnomedicine, 2(1), 35.

Causey, M. J. (2010). New archaeological discoveries from the Laikipia Plateau, Kenya. Azania: Archaeological Research in Africa, 45(1), 112-136.

Chamberlain, N. (2006). Report on the rock art of South West Samburu District, Kenya. Azania: Archaeological Research in Africa, 41(1), 139-157.

Charters, S., Evershed, R. P., Goad, L. J., Leyden, A., Blinkhorn, P. W., \& Denham, V. (1993). Quantification and distribution of lipid in archaeological ceramics: implications for sampling potsherds for organic residue analysis and the classification of vessel use. Archaeometry, 35(2), 211-223.

Charters, S., Evershed, R. P., Blinkhorn, P. W., \& Denham, V. (1995). Evidence for the mixing of fats and waxes in archaeological ceramics. Archaeometry, 37(1), 113-127.

Charters, S., Evershed, R. P., Quye, A., Blinkhorn, P. W., \& Reeves, V. (1997). Simulation experiments for determining the use of ancient pottery vessels: the behaviour of epicuticular leaf wax during boiling of a leafy vegetable. Journal of Archaeological Science, 24(1), 1-7.

Clarfield, G. (1989). Samburu Dorobo (Ndoto). In J. Barbour \& S. Wandibba (Eds.), Kenyan pots and potters (pp. 80-85). Nairobi: Oxford University Press.

Connan, J., Kozbe, G., Kavak, O., Zumberge, J., \& Imbus, K. (2013). The bituminous mixtures of Kavuşan Höyük (SE Turkey) from the end of the 3rd millennium (2000 BC) to the Medieval period (AD 14th century): composition and origin. Organic Geochemistry, 54, 2-18.

Copley, M. S., Rose, P. J., Clapham, A., Edwards, D. N., Horton, M. C., \& Evershed, R. P. (2001a). Detection of palm fruit lipids in archaeological pottery from Qasr Ibrim, Egyptian Nubia. Proceedings: Biological Sciences, 268(1467), 593-597.

Copley, M. S., Rose, P. J., Clapham, A., Edwards, D. N., Horton, M. C., \& Evershed, R. P. (2001b). Processing palm fruits in the Nile Valley_biomolecular evidence from Qasr Ibrim. Antiquity, 75(289), $538-542$.

Copley, M. S., Berstan, R., Dudd, S. N., Docherty, G., Mukherjee, A. J., Straker, V., Payne, S., \& Evershed, R. P. (2003). Direct chemical evidence for widespread dairying in prehistoric Britain. Proceedings of the National Academy of Sciences, 100(4), 1524-1529.

Copley, M. S., Bland, H. A., Rose, P., Horton, M., \& Evershed, R. P. (2005). Gas chromatographic, mass spectrometric and stable carbon isotopic investigations of organic residues of plant oils and animal fats employed as illuminants in archaeological lamps from Egypt. Analyst, 130(6), 860-871.

Correa-Ascencio, M., \& Evershed, R. P. (2014). High throughput screening of organic residues in archaeological potsherds using direct acidified methanol extraction. Analytical Methods, 6(5), 1330-1340.

Craig, O. E., Forster, M., Andersen, S. H., Koch, E., Crombe, P., Milner, N. J., Stern, B., Bailey, G. N., \& Heron, C. P. (2007). Molecular and isotopic demonstration of the processing of aquatic products in northern European prehistoric pottery. Archaeometry, 49(1), 135-152.

Cramp, L., \& Evershed, R. P. (2014). Reconstructing aquatic resource exploitation in human prehistory using lipid biomarkers and stable isotopes. In H. D. Holland \& K. K. Turekian (Eds.), Treatise on geochemistry (Second ed., pp. 319-339). Oxford: Elsevier.

Cramp, L. J. E., Evershed, R. P., \& Eckardt, H. (2011). What was a mortarium used for? Organic residues and cultural change in Iron Age and Roman Britain. Antiquity, 85(330), 1339-1352.

Cramp, L. J. E., Jones, J., Sheridan, A., Smyth, J., Whelton, H., Mulville, J., Sharples, N., \& Evershed, R. P. (2014). Immediate replacement of fishing with dairying by the earliest farmers of the northeast Atlantic archipelagos. Proceedings of the Royal Society B: Biological Sciences, 281(1780), 20132372.

Debono Spiteri, C., Gillis, R. E., Roffet-Salque, M., Castells Navarro, L., Guilaine, J., Manen, C., Muntoni, I. M., Saña Segui, M., Urem-Kotsou, D., Whelton, H. L., Craig, O. E., Vigne, J.-D., \& Evershed, R. P. 
(2017). Regional asynchronicity in dairy production and processing in early farming communities of the northern Mediterranean. Proceedings of the National Academy of Sciences, 113(48), 13594-13599.

Dudd, S. N., \& Evershed, R. P. (1998). Direct demonstration of milk as an element of archaeological economies. Science, 282(5393), 1478-1481.

Dunne, J., Evershed, R. P., Salque, M., Cramp, L., Bruni, S., Ryan, K., Biagetti, S., \& di Lernia, S. (2012). First dairying in green Saharan Africa in the fifth millennium BC. Nature, 486(7403), 390-394.

Dunne, J., Mercuri, A. M., Evershed, R. P., Bruni, S., \& Di Lernia, S. (2016). Earliest direct evidence of plant processing in prehistoric Saharan pottery. Nature Plants, 3, 1-6.

Evershed, R. P. (2008a). Experimental approaches to the interpretation of absorbed organic residues in archaeological ceramics. World Archaeology, 40(1), 26-47.

Evershed, R. P. (2008b). Organic residue analysis in archaeology: the archaeological biomarker revolution. Archaeometry, 50(6), 895-924.

Evershed, R. P., Heron, C., \& Goad, L. J. (1991). Epicuticular wax components preserved in potsherds as chemical indicators of leafy vegetables in ancient diets. Antiquity, 65(248), 540-544.

Evershed, R. P., van Bergen, P. F., Peakman, T. M., Leigh-Firbank, E. C., Horton, M. C., Edwards, D., Biddle, M., Kjolbye-Biddle, B., \& Rowley-Conwy, P. A. (1997a). Archaeological frankincense. Nature, 390(6661), 667-668.

Evershed, R. P., Vaughan, S. J., Dudd, S. N., \& Soles, J. S. (1997b). Fuel for thought? Beeswax in lamps and conical cups from late Minoan Crete. Antiquity, 71(274), 979-985.

Evershed, R. P., Dudd, S. N., Copley, M. S., Berstan, R., Stott, A. W., Mottram, H., Buckley, S. A., \& Crossman, Z. (2002). Chemistry of archaeological animal fats. Accounts of Chemical Research, 35(8), 660-668.

Evershed, R. P., Dudd, S. N., Anderson-Stojanovic, V. R., \& Gebhard, E. R. (2003). New chemical evidence for the use of combed ware pottery vessels as beehives in Ancient Greece. Journal of Archaeological Science, 30(1), 1-12.

Evershed, R. P., Payne, S., Sherratt, A. G., Copley, M. S., Coolidge, J., Urem-Kotsu, D., Kotsakis, K., Ozdogan, M., Ozdogan, A. E., Nieuwenhuyse, O., Akkermans, P., Bailey, D., Andeescu, R. R., Campbell, S., Farid, S., Hodder, I., Yalman, N., Ozbasaran, M., Bicakci, E., Garfinkel, Y., Levy, T., \& Burton, M. M. (2008). Earliest date for milk use in the Near East and Southeastern Europe linked to cattle herding. Nature, 455(7212), 528-531.

Galvin, K. A. (1992). Nutritional ecology of pastoralists in dry tropical Africa. American Journal of Human Biology, 4(2), 209-221.

Gannes, L. Z., O'Brien, D. M., \& Martínez del Rio, C. (1997). Stable isotopes in animal ecology: assumptions, caveats, and a call for more laboratory experiments. Ecology, 78(4), 1271-1276.

Gregg, M. W., Banning, E. B., Gibbs, K., \& Slater, G. F. (2009). Subsistence practices and pottery use in Neolithic Jordan: molecular and isotopic evidence. Journal of Archaeological Science, 36(4), 937-946.

Grillo, K. M. (2012). The materiality of mobile pastoralism: ethnoarchaeological perspectives from Samburu, Kenya. Unpublished $\mathrm{PhD}$ thesis, Washington University in St. Louis.

Grillo, K. M. (2014). Pastoralism and pottery use: an ethnoarchaeological study in Samburu, Kenya. African Archaeological Review, 31(2), 105-130.

Hansel, F. A., \& Evershed, R. P. (2009). Formation of dihydroxy acids from Z-monounsaturated alkenoic acids and their use as biomarkers for the processing of marine commodities in archaeological pottery vessels. Tetrahedron Letters, 50(40), 5562-5564.

Hansel, F. A., Copley, M. S., Madureira, L. A. S., \& Evershed, R. P. (2004). Thermally produced [omega]-(oalkylphenyl)alkanoic acids provide evidence for the processing of marine products in archaeological pottery vessels. Tetrahedron Letters, 45(14), 2999-3002.

Heron, C., Nemcek, N., Bonfield, K. M., Dixon, D., \& Ottaway, B. S. (1994). The chemistry of Neolithic beeswax. Naturwissenschaften, 81(6), 266-269.

Historic England (2017). Organic residue analysis and archaeology: guidance for good practice.

Hodder, I. (1982). Symbols in action: ethnoarchaeological studies of material culture. Cambridge: Cambridge University Press.

Holtzman, J. (2003). In a cup of tea: commodities and history among Samburu pastoralists in northern Kenya. American Ethnologist, 30(1), 136-155.

Holtzman, J. (2007). Eating time: capitalist history and pastoralist history among Samburu herders in northern Kenya. Journal of Eastern African Studies, 1(3), 436-448.

Holtzman, J. (2009). Uncertain tastes: memory, ambivalence, and the politics of eating in Samburu, northern Kenya. Berkeley: University of California Press.

Iannotti, L., \& Lesorogol, C. (2014a). Dietary intakes and micronutrient adequacy related to the changing livelihoods of two pastoralist communities in Samburu, Kenya. Current Anthropology, 55(4), 475-482. 
Iannotti, L., \& Lesorogol, C. (2014b). Animal milk sustains micronutrient nutrition and child anthropometry among pastoralists in Samburu, Kenya. American Journal of Physical Anthropology, 155(1), 66-76.

Lane, P. (2011). An outline of the later Holocene archaeology and precolonial history of the Ewaso Basin, Kenya. In N. Georgiadis (Ed.) Conserving wildlife in African landscapes: Kenya's Ewaso ecosystem (pp. 11-30). Smithsonian Contributions to Zoology, no. 632.

Lane, P., Straight, B., \& Hilton, C. (2007). Excavations at Baawa, Samburu District, Kenya: Preliminary report on the 2006 season. Nyame Akuma, 68, 34-46.

Larick, R. (1986). Iron smelting and interethnic conflict among precolonial Maa-speaking pastoralists of north-central Kenya. African Archaeological Review, 4(1), 165-176.

Lemonnier, P. (1986). Study of material culture today: toward an anthropology of technical systems. Journal of Anthropological Archaeology, 5(2), 147-186.

Lesorogol, C. K. (2008). Contesting the commons: privatizing pastoral lands in Kenya. Ann Arbor: The University of Michigan Press.

Little, M. A., Gray, S. J., \& Campbell, B. C. (2001). Milk consumption in African pastoral peoples. In I. de Garine \& V. de Garine (Eds.), Drinking: anthropological approaches (pp. 66-86). New York: Berghahn Books.

Mills, J. S., \& White, R. (1989). The identity of the resins from the Late Bronze Age shipwreck at Ulu Burun (Kaș). Archaeometry, 31(1), 37-44.

Morgan, W. T. W. (1981). Ethnobotany of the Turkana: use of plants by a pastoral people and their livestock in Kenya. Economic Botany, 35(1), 96-130.

Mukherjee, A. J., Copley, M. S., Berstan, R., Clark, K. A., \& Evershed, R. P. (2005). Interpretation of $\delta^{13}$ C values of fatty acids in relation to animal husbandry, food processing and consumption in prehistory. In J. Mulville \& A. Outram (Eds.), The zooarchaeology of milk and fats (pp. 77-93). Oxford: Oxbow Books.

Outram, A. K., Stear, N. A., Bendrey, R., Olsen, S., Kasparov, A., Zaibert, V., Thorpe, N., \& Evershed, R. P. (2009). The earliest horse harnessing and milking. Science, 323(5919), 1332-1335.

Patrick, M., de Koning, A. J., \& Smith, A. B. (1985). Gas liquid chromatographic analysis of fatty acids in food residues from ceramics found in the Southwestern Cape, South Africa. Archaeometry, 27(2), 231236.

Reber, E., Dudd, S., Van der Merwe, N., \& Evershed, R. (2004). Direct detection of maize processing in archaeological pottery through compound-specific stable isotope analysis of n-dotriacontanol in absorbed organic residues. Antiquity, 78(301), 682-691.

Regert, M., Colinart, S., Degrand, L., \& Decavallas, O. (2001). Chemical alteration and use of beeswax through time: accelerated ageing tests and analysis of archaeological samples from various environmental contexts. Archaeometry, 43(4), 549-569.

Roffet-Salque, M., Regert, M., Evershed, R. P., Outram, A. K., Cramp, L. J. E., Decavallas, O., Dunne, J., Gerbault, P., Mileto, S., Mirabaud, S., Pääkkönen, M., Smyth, J., Šoberl, L., Whelton, H. L., Alday-Ruiz, A., Asplund, H., Bartkowiak, M., Bayer-Niemeier, E., Belhouchet, L., Bernardini, F., Budja, M., Cooney, G., Cubas, M., Danaher, E. M., Diniz, M., Domboróczki, L., Fabbri, C., González-Urquijo, J. E., Guilaine, J., Hachi, S., Hartwell, B. N., Hofmann, D., Hohle, I., Ibáñez, J. J., Karul, N., Kherbouche, F., Kiely, J., Kotsakis, K., Lueth, F., Mallory, J. P., Manen, C., Marciniak, A., Maurice-Chabard, B., Mc Gonigle, M. A., Mulazzani, S., Özdoğan, M., Perić, O. S., Perić, S. R., Petrasch, J., Pétrequin, A.-M., Pétrequin, P., Poensgen, U., Joshua Pollard, C., Poplin, F., Radi, G., Stadler, P., Stäuble, H., Tasić, N., Urem-Kotsou, D., Vuković, J. B., Walsh, F., Whittle, A., Wolfram, S., Zapata-Peña, L. \& Zoughlami, J. (2015). Widespread exploitation of the honeybee by early Neolithic farmers. Nature,527, 226-230.

Roffet-Salque, M., Dunne, J., Altoft, D. T., Casanova, E., Cramp, L. J. E., Smyth, J., Whelton, H., \& Evershed, R. P. (2017). From the inside out: upscaling organic residue analyses of archaeological ceramics. Journal of Archaeological Science: Reports, 16, 627-640.

Salque, M. (2012). Regional and chronological trends in milk use in prehistoric Europe traced through molecular and stable isotope signatures of fatty acyl lipids preserved in pottery vessels. Unpublished $\mathrm{PhD}$ thesis, University of Bristol.

Shaabani, S. B., Walsh, M., Herlocker, D. J. \& Walther, D. (1992). Range management handbook of Kenya, Volume II, Samburu District, Republic of Kenya, Ministry of Livestock Development (MOLD), Nairobi.

Shoda, S., Lucquin, A., Ahn, J.-h., Hwang, C.-j., \& Craig, O. E. (2017). Pottery use by early Holocene huntergatherers of the Korean peninsula closely linked with the exploitation of marine resources. Quaternary Science Reviews, 170, 164-173.

Siiriäinen, A. (1977). Later Stone Age investigation in the Laikipia Highlands, Kenya: a preliminary report. Azania: Archaeological Research in Africa, 12(1), 162-186.

Skibo, J. M. (1992). Pottery function: a use-alteration perspective. New York: Plenum Press. 
Spangenberg, J. E., Jacomet, S., \& Schibler, J. (2006). Chemical analyses of organic residues in archaeological pottery from Arbon Bleiche 3, Switzerland-evidence for dairying in the late Neolithic. Journal of Archaeological Science, 33(1), 1-13.

Spencer, P. (1965) The Samburu: a study of gerontocracy in a nomadic tribe. Berkeley: University of California Press.

Spencer, P. (1973). Nomads in alliance: symbiosis and growth among the Rendille and Samburu of Kenya. London: Oxford University Press.

Stern, B., Heron, C., Corr, L., Serpico, M., \& Bourriau, J. (2003). Compositional variations in aged and heated Pistacia resin found in Late Bronze Age Canaanite amphorae and bowls from Amarna, Egypt. Archaeometry, 45(3), 457-469.

Stern, B., Connan, J., Blakelock, E., Jackman, R., Coningham, R. A. E., \& Heron, C. (2008). From Susa to Anuradhapura: reconstructing aspects of trade and exchange in bitumen-coated ceramic vessels between Iran and Sri Lanka from the third to the ninth centuries AD. Archaeometry, 50(3), 409-428.

Stott, A. W., Berstan, R., \& Evershed, R. P. (2003). Direct dating of archaeological pottery by compoundspecific C-14 analysis of preserved lipids. Analytical Chemistry, 75(19), 5037-5045.

Straight, B. (2008). Killing God: exceptional moments in the colonial missionary encounter. Current Anthropology, 49(5), 837-860.

Urem-Kotsou, D., Stern, B., Heron, C., \& Kotsakis, K. (2002). Birch-bark tar at Neolithic Makriyalos, Greece. Antiquity, 76(294), 962-967.

van Bergen, P. F., Peakman, T. M., Leigh-Firbank, E. C., \& Evershed, R. P. (1997). Chemical evidence for archaeological frankincense: Boswellic acids and their derivatives in solvent soluble and insoluble fractions of resin-like materials. Tetrahedron Letters, 38(48), 8409-8412. 